\title{
Students' Perception in Learning English through Communicative English Club (CEC) at IAIN Salatiga
}

\author{
Eni Suriyah ${ }^{\mathrm{a}}$, Mazulfah ${ }^{\mathrm{b}}$ \\ ${ }^{\mathrm{a}, \mathrm{b}}$ Institut Agama Islam Negeri Salatiga, Indonesia \\ Email of corresponding author: mmazulfah@gmail.com
}

\begin{abstract}
The purposes of this study were (1) to know how is perceptions of student in learning English through Communicative English Club (CEC) IAIN Salatiga and (2) to know how is the student's perception of the stimulus for the English material given by the Communicative English Club (CEC) IAIN Salatiga. This study uses qualitative research to find out the purposes. Sample is chosen by the researcher or called a purposive sample. Six students who joined in Communicative English Club (CEC) were interviewed. From the results of this study, it is concluded that students who join the Communicative English Club (CEC) Student Activity Unit (UKM) had a positive perception of learning English at CEC and the materials that were given. CEC activities or work programs improve their English language skills, especially speaking skills. Although not aiming to learn English, students got an experience of learning English at CEC that is different from learning in the classroom. They got the opportunity to practice English more often. In addition, CEC provides environmental and mental support for learning English. Students consider English material to be not just written grammar material, but English material can be obtained through an environment, discussion, and experience that can improve their English language skills.
\end{abstract}

Keywords: students' perception, learning, English, English club

\section{INTRODUCTION}

In general, English learning is carried out in schools at certain hours that have been determined by the Ministry of Education and Culture and the time and day are scheduled by the school. At IAIN Salatiga, English is a compulsory subject that must be met by students with a minimum grade of B. The English course is divided into two, namely English 1 and English 2 which is a sequel where English 2 can be taken if English 1 has been completed. Since the Covid-19 pandemic, lectures have been conducted online and there is no face-to-face learning in class starting from the even semester of 2020. Then on November 10, 2021, limited face-to-face learning was implemented at IAIN Salatiga so that students get the opportunity to study in class with friends and lecturers which of course must comply with health protocols.

In learning process, it is not enough for students to be able to acquire English language skills. Amelia et al., (2017:1) in his Conference Proceeding admitted that learning English in the classroom was not effective due to limited time for both students and teachers. This is evidenced by the low English proficiency of college-level students (Megawati, 2016). 
Field facts obtained through observations and interviews with students show that they have limited time to practice English, while in class they are only given material. They cannot understand the material well because the class situation is not conducive. Moreover, the students did not have the courage to ask the lecturers when they did not understand the material presented. Students feel that communicating to English lecturers is very awkward and scary because some lecturers ask students to talk to them in English during class. As a result, students formally attend lectures and get standard or low grades without having the ability to speak English well.

To overcome this, some students choose to join an organization or student activity unit based on English which is also recommended by Yuliandasari \& Kusriandi (2015:305). One of the English Clubs at IAIN Salatiga is Communicative English Club or abbreviated as CEC. CEC is a student activity unit that has a decree from the Chancellor and is domiciled at the institute level. This club was founded on November 17, 1997 and has the aim of developing student interest in the field of English as a compulsory subject in the curriculum and for future careers, as well as fostering a healthy organizational life for students. In this English club, there are 66 management members and all IAIN Salatiga students can participate in various activities held as participants. Students who act as board members have an obligation to learn English and organize various activities related to English. This certainly encourages students to have additional time to practice and learn English with friends who have the same interest in the field of English at this English club. They also get support from the environment to learn English.

Joining an English club has a positive impact on students' speaking skills (Yuliandasari \& Kusriandi, 2015:305), increase motivation and confidence to practice speaking (Hanim, 2018:53), provide a wide range of practice (Zulhermindra, 2018), interesting and effective (Amelia et al., 2017) and critical thinking (Awalya et al., 2010). In other studies, team enjoyment and team cooperation are the most influential on learning outcomes (Mohammad-davoudi \& Parpouchi, 2016:184).

Likewise, students in learning English need to look for opportunities outside the classroom. By joining an English club, they can also add to their network of friends. The network communication they have can help them discuss and solve their English problems (Palfreyman, 2018:4).

Students studied at the Communicative English Club (CEC), they got various stimuli to learn English. This stimulus will form a perception. Perception is a process that is preceded by the sensing process, which is the process of receiving the stimulus by the individual through the senses or also called the sensory process. However, the process does not just stop, but the stimulus is continued and the next process is a perception process. The sensed stimulus is then organized and interpreted by the individual, so that the individual is aware of, understands, about what is sensed, and this process is called perception. (Saleh, 2018:80). 
Based on the facts and previous research, The researchers were interested in examining Students' Perception in Learning English through the communicative English Club (CEC) at IAIN Salatiga. In previous studies, it has been explained that there are many benefits of learning English through the English club. In this study the researchers wanted to see how students perceive after studying at the Communicative English Club (CEC). Researchers also wanted to provide an overview of how students understand the stimulus received from this English Club.

\section{Perception}

Perception is a technique with the aid of using which people arrange and interpret their sensory impressions for you to deliver that means to their environment (Robbins \& Judge, 2013:166). Perception (from Latin perceptio, percipio) is the occasion of compiling, recognizing, and decoding sensory statistics for you to offer an outline and expertise of the environment (Couto, 2016:14). Perception is crucial to have a look at any area due to the fact people`s conduct is primarily based totally on their belief of what truth is, now no longer on truth itself.

In the book Organizational Behavior (Robbins \& Judge, 2013:167), there are 3 factors that influence perception, namely: the perceiver; in the object, or target, being perceived; or in the context of the situation in which the perception is made. Factor from the perceiver including attitudes, personality, motives, interests, past experiences, and expectations. Factors from the target being perceived are novelty, motion, sounds, size, background, proximity, and similarity. Factors in the situation are time, work setting, and social setting.

Meanwhile, Saleh (2018: 80) explains the factors that play a role in perception. These factors are:

a. Perceived object.

Perceived objects can be anything such as movable objects, immovable objects, living objects, and inanimate objects. The object can act as a stimulus but it is not certain that the object is also a stimulus. Objects can provide a stimulus but the object is not a stimulus.

b. Sensory organs, nerves, and central nervous system the sense organs or receptors are tools for receiving stimuli.

In addition, there must also be sensory nerves as a tool to transmit the stimulus that is received by the receptor to the central nervous system, namely the brain as the center of consciousness. As a tool to carry out a response, motor nerves are needed.

c. Attention

To realize or to hold a perception requires attention. Attention is the first step as a preparation in order to make a perception. Attention is the concentration or concentration of all individual activities that are shown to something or a group of objects. 
The procedure of perception is while the item reasons a stimulus, and the stimulus hits the senses or receptors. It has to be said that the item and stimulus are different, however there are instances while the item and stimulus end up one, as an example the case of stress. The item without delay hits the skin, so that you will sense the pressure. The stimulus procedure concerning the senses is a natural procedure. The stimulus acquired through the feel organs is transmitted through the sensory nerves to the mind. This procedure is referred to as a physiological procedure. Then there may be a procedure within side the mind because the middle of focus in order that people comprehend what they see, or what they hear, or what they sense. The procedure that happens within side the mind or within side the middle of focus is referred to as a mental procedure. Thus, it may be argued that the ultimate nerve of the perceptual procedure is that the character is conscious of, as an example, what's seen, what's heard, or what's touched, specifically the stimulus that is surpassed through the senses. This procedure is the ultimate procedure of belief and is the real belief. Responses due to belief may be taken through people in diverse forms. Individuals get hold of a whole lot of stimuli that come from the environment. But now no longer all might be observed or might be given a response. The character makes a choice of the stimulus that hits him, and interest performs a position here. As a result of the stimulus this is selected and normal through the character, the character realizes and responds as a response to the stimulus.

\section{English Club}

English extracurricular club is a further English language mastering pastime this is carried outside of normal faculty hours which objectives to enhance the capacity of college students in the subject of English and additionally as a facility for college students who like English to educate and enhance their English skills. An English club is a company of humans with same motive or interest, who meet frequently and participate in shared activities. An English Club is an area for language newcomers to apply English in an informal placing and it's miles in a spare school room at an English faculty (Elnadeef \& Abdala, 2019). According Kathleen and Smedley English club is a set of human beings or club contributors who meet frequently to exercise speaking, listening, reading, and writing in English and English club is a sequence of frequently scheduled conferences where in club contributors exercise English and assist the network remedy problem (Malu \& Smedley, 2013). In addition, English club is learning method by group to make their members can use language in communication (Armita, 2019).

Melviza et al said that English club is a media as a connector one man or woman to the others which the reason now no longer simplest to enhance speaking capacity however additionally to enhance college students motivation and to make the learner to be confident to talk as lots as possible (Melviza et al., 2017:101). English club pursuits at assisting the scholars increase a nice mind-set toward the English language and to be sensitized to the speaking in English. They aren't lecture rooms with instructors and 
students. They are safe, nurturing, supportive environments in which folks who desire to immerse themselves in English for some hours can do so (Malu \& Smedley, 2013:23).

\section{METHOD}

This research used qualitative methods in its implementation. Qualitative research was research that produced findings that could not be achieved used statistical procedures or quantitative methods (Sidiq \& Choiri, 2019:3). This research emphasizes on quality not quantity. The design is phenomenology. The purpose of this research is to get an answer to the phenomenon through the application of scientific procedures systematically with a qualitative approach. There are two variables in this study. Students' Perception of the dependent variable (Y) and Learning English as through Communicative English Club (CEC) at IAIN Salatiga is the independent variable (Y).

The population in this study were the entire board of the Communicative English Club (CEC) IAIN Salatiga, totaling 66 people. Purposive sampling is used in qualitative research. That is, there is no random sample but a purposeful sample (Salim \& Syahrum, 2012:141). The sample is 6 IAIN Salatiga students who join the Communicative English Club (CEC) student activity unit for at least one year.

The data collection procedure was carried out to explore students' perceptions in learning English through the Communicative English Club (CEC), namely interview and observation. Interview is a technique of extracting data through conversation with a specific purpose from two or more parties. In depth interviewing was chosen as the interview model for this research. Interviews are conducted in non-formal situations, not strict, and open like everyday conversations. The goal is to be able to present the current construction in a context regarding personal and perceptions of the variables that are studied. The next procedure is observation. Researchers need to make observations in order to analyze the behavior of the population being studied. Observations were also made so that researchers would not only focus on the sample subject but on other objects in the Communicative English Club.

The implementation of data analysis in qualitative research is a process of systematically searching and compiling data obtained from interviews, field notes, and other materials, so that they can be understood easily, and the findings can be informed to others (S. Saleh, 2017). The researchers used the Miles and Huberman model which consists of 3 stages of data analysis, namely data reduction, data presentation, and conclusions. Data reduction was used to filter information from the interviews conducted.

\section{FINDINGS AND DISCUSSION}

Findings got from the interview are scripted below:

Translation: 
P1 : First off, I'm at CEC looking for the connection and environment I need. Moreover, I majored in English and it made it a habit to study English and CEC also focused on English. Now at CEC also teaches a lot how to learn several skills such as speaking, reading, and grammar and it can improve my English skills. What's more, I was trusted as the chairman, I automatically had to speak up and if I had to speak English, it greatly improved my English skills. The second is material about English at CEC. The administrators themselves have provided material, one of which is TOEFL prediction. We learn about TOEFL, listening, structure and written expression and reading. There we summarize the material in Longman's TOEFL, then we will simplify it using Indonesian. Maybe it can be for novice students and the material is interesting and easy to learn. As for the environment, because our vision and mission is to be interested in English, we are both learning English and that makes us even more intensive in learning English.

P2 : Talking about my perception of learning English at CEC, it's normal because my goal from the beginning to participate in CEC activities was just to find relationships, make friends, and spend my time other than lectures or outside class hours. However, when you start participating in activities at CEC or become active in organizations, activities at CEC can improve your English skills, especially speaking. At CEC there are activities that require me to speak in English even if only a few times, bilingual or mixed with Indonesian. For example, when I have a speech at an event as vice chairman. So in that case I learned how to give a speech in English. There are also certain days where we are required to do activities and games in English. With these activities, I unconsciously realized that these activities could improve my speaking skills. Because since semester 4 we have to undergo online lectures. In online class could not help me much to learn English. So, the CEC activities encouraged me to improve my English skills.

P3 : To be honest, before I enrolled at UKM CEC I never expected to learn English there. Instead, I expected to learn English not from CEC but from myself. So, I learn English through my knowledge outside of CEC to pass it on or to share that experience at CEC. The concept is that I want to teach English instead of learning English. Learning English at CEC that I experienced was not academic but practical, such as how I roast someone using English, then tell English jokes, and also, I even got fluency in speaking from CEC activities.

P4 : The first is about learning English at CEC, actually I entered CEC just to gain experience, to increase relationships, and I joined this CEC organization actually to improve my English, and after I entered CEC I could have a lot of experience. The first is to participate in every activity etc. which makes me very active and then to learn English at CEC, I learn indirectly, I can learn many things about English at CEC. Regarding the material taught at CEC, I got a lot of experience and knowledge that I got. The first one creates a module. Honestly, it's my first time to make a module for English and I can get through it. That way I can have experience in the field of English. 
Second, there are active activities about English such as CEC Festival, International Seminar held by CEC. That I get a lot of material from CEC.

P5: The first is about learning English at CEC. Actually, to enter CEC I did not pursue learning or acquiring English knowledge, but also, I pursued how to socialize and make many friends. Well, according to my perception to learn English at CEC. Here CEC is an English-based SME. Here there is a work program or work program that teaches or in it there is an emphasis on how to improve the English language. For the English language learning itself at CEC, in my perception, it is lacking in implementation or practice in the field, and there are still many who use Javanese or Indonesian communication. Then the English material at CEC is in the form of work programs as I mentioned earlier, for example TOEFL, an international seminar in which there are ways to improve or enrich our knowledge of the English language.

P6 : My perception of learning English at CEC is that the learning is very different from what I get in class. At CEC I found people who are not ashamed to use English even if their grammar is wrong. They are people who want to learn English through CEC. Of course not all members of the CEC are like that but I found some like that. I feel more like I have friends to be my speaking partner, friends to discuss about English, English competitions and discussions about scholarships. CEC gave me the opportunity to take part in an English competition where CEC and the administrators supported me by helping me practice. The material provided by CEC is not only written text books but also a supportive environment for speaking English, mental support to dare to practice English. Even though in fact at CEC we don't always use English, this is where I can find a partner to learn English together and practice it little by little.

The analysis results from the interview data that each student has different intentions and goals to join the Communicative English Club (CEC). From 4 out of 6 students stated that the purpose of joining CEC is to increase their relationship "I'm at CEC looking for the connection,...", “...to find relationships...", "..to increase relationships...", “...I pursued how to socialize and make many friends...". The majority of students do not aim to learn English. However, two students stated that they wanted to find an environment that supports the practice of English such as ".... and environment I need..." and "...I found people who are not ashamed to use English even if their grammar is wrong...". From student statements through interviews, they participated in CEC activities to increase their relationships and wanted to get an environment that supports them in learning English.

As long as students join CEC, they have various work programs which are of course English-based. Some of the work programs mentioned are CEC Festival, International Seminar, Making Modules, TOEFL Training, and TOEFL Preparation Test. The student committee members of the CEC played major role as a committee to carry out the work program. The work program is aimed at educating CEC board members in particular and IAIN Salatiga students in general. CEC Festival is an English language competition 
for junior high school students, high school students, and college students throughout Central Java. Contests are held such as singing contests, storytelling, debate, and speech. The international seminar is a seminar with speakers and participants from Indonesia and abroad. The entire series of events is conducted in English. As for making modules, TOEFL training, and TOEFL Preparation tests are a series of ongoing activities. First, CEC administrators write modules related to English material. Then CEC advertises and invites students to take TOEFL training held by CEC. The training was carried out for approximately three months online using the What's App Group as the media. As a final stage, the TOEFL Preparation Test is given to TOEFL training participants and IAIN Salatiga students who want to measure their English skills. Many other work programs also always involve English, such as study clubs and debate exhibitions.

From the CEC work program, CEC management students consciously and unconsciously learn English. One student said “...I was trusted as the chairman, I automatically had to speak up and if I had to speak English...", and another student replied "when I have a speech at an event as vice chairman. So in that case I learned how to give a speech in English." They were initially forced to apply English in terms of giving the opening speech of an event or activity. Another student also said, "...The first is to participate in every activity etc. which makes me very active and then to learn English at CEC,..." and "...Here there is a work program or work program that teaches or in it there is an emphasis on how to improve the English language....". Participating in every activity also provides them with an English learning experience.

The most improved English skill is speaking. This is based on the students' expressions, “...activities at CEC can improve your English skills, especially speaking....”, “...I even got fluency in speaking from CEC activities.", “.... supportive environment for speaking English...". This gives an idea that at CEC students practice speaking English. However, in reality, students who join CEC do not fully speak English when they meet. This was conveyed by one of the students who said that at CEC they are lacking in implementation or practice in the field, and there are still many who use Javanese or Indonesian communication.

Learning at CEC was not learning in the classroom. Students got a different experience from learning English in the classroom. They learnt English at CEC in full in a supportive environment. Even though they had different goals and backgrounds, they were united in the Communicative English Club or CEC student activity unit. They were required to be individuals who could hold English-language activities and support these activities, so all CEC member students must support anyone to learn English. Some forms of support include being a partner in practicing speaking skills, providing English reading resources at the CEC secretariat office, providing a forum for discussing English, and helping each other such as providing scholarship information and preparing for competitions. Moreover, all CEC members support anyone who wants 
to learn English. They do not blame when other friends make mistakes in learning English but they provide input.

\section{CONCLUSION}

From the results of this study, it could be said that students who joined the Communicative English Club (CEC) had a positive perception of learning English at CEC. CEC activities or work programs improved their English language skills, especially speaking skills. Students got an experience of learning English at CEC that was different from learning in the classroom. They got the opportunity to practice English more often. In addition, CEC provided environmental and mental support for learning English.

The students' perception of the material given at CEC was good. Students considered English material not only written grammar material, but also English material could be obtained through an environment, discussion, and experience that could be improved to their English language skills.

\section{REFERENCES}

Amelia, F., Novitasari, N. F., \& Firdaus, A. Y. (2017). Bridging The Gaps in Curriculum to Students Tthrough English Club. Proceedings (International Seminar on Language, Education, and Culture), 56-61.

Armita, Y. (2019). Students' Perception Toward English Club Extracurricular Activities in Practicing Speaking at SMA N 02 Kaur, Bengkulu. IAIN Bengkulu, Bengkulu.

Awalya, S. S., Handayani, I., \& Rahmawati, E. (2010). Students 'Perception on the Use of English Debate Extracurricular to Improve Students ' Speaking and Critical Thinking Skill in SMA La Tansa. AISELT (Annual International Seminar on English Language Teacing), 234-248. Retrieved from https://jurnal.untirta.ac.id/index.php/aiselt/article/view/11062\&ved=2ahUKEwj_ msGQ5Ib1 AhXQT2wGHVGtCu8QFnoECAgQAQ\&usg=AOvVaw2TI5zobv0N7 DpvVMokwBw-

Couto, A. M. (2016). Psikologi Persepsi \& Desain Informasi (Sebuah Kajian Psikologi Persepsi dan Prinsip Kognitif untuk Kependidikan dan Desain Komunikasi Visual). Yogyakarta: Media Akademi.

Elnadeef, E. A. E., \& Abdala, A. H. E. H. (2019). The Effectiveness of English Club as Free Voluntary Speaking Activity Strategy in Fostering Speaking Skill in Saudi Arabia Context The Effectiveness of English Club as Free Voluntary Speaking Activity Strategy in Fostering Speaking Skill in Saudi Arabia C. International Journal of Linguistics, Literature and Translation (IJLLT) ISSN, 2(1), 231-236. https://doi.org/10.32996/ijllt.2019.2.1.28 
Hanim, I. (2018). The Learners 'Perceptions of Speaking English at Lia Pramuka English Club. Globish (An English-Indonesian Journal for English, Education and Culture), 7(1), 53-60. Retrieved from http://103.131.16.137/index.php/globish/article/viewFile/665/pdf\&ved=2ahUKEw jrxJeL5Yb1 AhUL8HMBHQVTAfAQFnoECAQQAQ\&usg=AOvVaw3v6nnpq3 DPZ1 KGqPDKN5Vg

Malu, K. F., \& Smedley, B. (2013). Community-Based English Clubs : English Practice and Social Change Outside the Classroom. In English Teaching Forum. americanenglish.state.gov/english-teaching-forum

Megawati, F. (2016). Kesulitan Mahasiswa dalam Mencapai Pembelajaran Bahasa Inggris Secara Efektif. Jurnal Pedagogia, 5(2), 147-156. https://doi.org/10.21070/pedagogia.v5i2.246

Melviza, Z., Ys, S. B., \& Erdiana, N. (2017). Students' Perception Toward English Club Activities. Research in English and Education (READ), 2(2), 101-109. Retrieved from

http://jim.unsyiah.ac.id/READ/article/view/5771\&ved=2ahUKEwi509fg5Yb1 Ah Xm4nMBHW0cB18QFnoECBAQAQ\&usg=AOvVaw2pv28PWGNy6Bf-LLJyBQj

Mohammad-davoudi, A. H., \& Parpouchi, A. (2016). Relation between team motivation , enjoyment, and cooperation and learning results in learning area based on teambased learning among students of Tehran University of medical science. Procedia - Social and Behavioral Sciences, 230, 184-189. https://doi.org/10.1016/j.sbspro.2016.09.023

Ngadimun, Purwanti, R., Suriansyah, A., \& Maimunah. (2019). Empowerment of "english club" to influence students achievement in speaking. International Journal of Innovation, Creativity and Change, 5(5), 204-216. Retrieved from https://repodosen.ulm.ac.id/handle/123456789/19524\&ved=2ahUKEwiRspn85Yb1 AhVe83 MBHfOSCJUQFnoECAYQAQ\&usg=AOvVaw0X-LBB1Z2mPZ7E8k9CWHhl

Palfreyman, D. M. (2018). Chapter 2 Family, friends and learning beyond the classroom: Social networks and social capital in language learning (Issue January 2011, pp. 2-26). https://doi.org/10.1057/9780230306790

Robbins, S. P., \& Judge, T. A. (2013). Organizational Behaviour (15th Editi). New Jersey: PEARSON.

Saleh, A. A. (2018). Pengantar Psikologi. Makassar: Penerbit Aksara Timur.

Saleh, S. (2017). Analisis Data Kualitatif; Cetakan Pertama. Bandung: Penerbit Pustaka Ramadhan.

Salim, \& Syahrum. (2012). Metodologi Penelitian Kualitatif . Bandung: Citapustaka 
Media.

Sidiq, U., \& Choiri, M. (2019). Metode Penelitian Kualitatif di Bidang Pendidikan (A. Mujahidin (ed.); Cetakan Pertama. Ponorogo: CV. Nata Karya.

Umar. (2016). The Effects of the English Club Program on Students Speaking Achievement at The Third Semester of STKIP Paracendekia N W Sumbawa. Jurnal UNSA Progres, 21(3), 72-76. Retrieved from https://www.researchgate.net/publication/341592705_The_Effects_of_the_Englis h_Club_Program_on_Students_Speaking_Achievement_at_The_Third_Semester_ of_STKIP_Paracendekia_N_W_Sumbawa

Wardatun, I. (2020). Exploring The Advantages of English Club on Students' Speaking Skill. In IEEE Transactions on Circuits and Systems II: Express Briefs. UIN ArRaniry, Banda Aceh. Retrieved from http://jurnal.ugj.ac.id/index.php/Perspective/article/view/1670\&ved=2ahUKEwjB 56bn6Ib1AhWe7XMBHQvhCVgQFnoECAcQAQ\&usg=AOvVaw2dvBq9GIA07 6Re_nN9m8x-

Yuliandasari, A., \& Kusriandi, W. (2015). Students' Perception on English Club Extracurricular in Speaking Practices at Madrasah. ELT Perspective, 3(2), 305315.

Zulhermindra. (2018). Promoting English Club as an Extracurricular Activity for Young Learners: Suggested Procedure. 3rd International Conference on Education, 286288. 